\title{
Analisis Pengaruh Penambahan Jalur MRT Fase 2A terhadap Track Maintenance Section (Lintas Lebak Bulus - Kota)
}

\author{
Bambang Winarto, Muhammad Dhiyaa Islami, Ricko Yudhanta \\ KERETA API INDONESIA PERSERO \\ Email: bambangwinarto@gmail.com
}

\begin{abstract}
Abstrak
Tujuan penelitian ini adalah untuk menganalisis pengaruh penambahan jalur MRT fase 2a terhadap track maintenance section (lintas lebak bulus - kota). Penelitian ini menggunakan jenis penelitian kualitatif dengan pendekatan analisis deskriptif. Jenis data yang digunakan dalam penelitian ini berjenis data primer dan data sekunder yang diperoleh dari hasil pengamatan di lapangan maupun intansi terkait, selanjutnya data tersebut diproses mulai dari meng-input sampai didapatkan output melalui analisis dengan metodemetode yang dapat diterima secara ilmiah: 1) Mengidentifikasi masalah; 2) pengumpulan data; 3) pengolahan data; dan 4) keluaran. Berdasarkan hasil penelitian ini dapat disimpulkan hasil dari perhitungan beban kerja pada Track Maintenance Section MRT Jakarta, setelah pembangunan fase 2a dibutuhkan 2 orang pegawai dengan pendidikan di bidang perkeretaapian setingkat Diploma III atau lulus pendidikan sekolah lanjutan tingkat atas dan lulus pendidikan dan pelatihan dasar Tenaga Pemeriksa Jalur Kereta Api.
\end{abstract}

Kata Kunci: Analis, Pengaruh, Penambahan jalur, MRT.

\section{Abstract}

The purpose of this study was to analyze the effect of adding the MRT line phase 2 a to the track maintenance section (cross Lebak Bulus - Kota). This research uses qualitative research with descriptive analysis approach. The types of data used in this study are primary data and secondary data obtained from observations in the field and related agencies, then the data is processed starting from inputting to getting output through analysis using scientifically acceptable methods: 1) Identify the problem; 2) data collection; 3) data processing; and 4) output. Based on the results of this study, it can be concluded that the results of the calculation of the workload on the Track Maintenance Section of the MRT Jakarta, after the construction of phase 2 a, it takes 2 employees with education in the railway sector at the Diploma III level or graduated from high school education and passed the basic education and training of Track Inspector Staff. Train.

Keywords: Analyst, Influence, Addition of lines, MRT. 


\section{A. PENDAHULUAN}

Sistem transportasi merupakan suatu rangkaian dari kegiatan yang mempunyai hubungan satu dengan lainnya yang ditujukan untuk mencapai suatu tujuan dengan cara yang aman, nyaman, mudah, dan ekonomis. Di mana dalam proses transportasi tersebut melibatkan manusia, barang, alat angkut pada suatu ruang sebagai tempat pergerakan. Dengan berkembangnya ruang tersebut meningkat pula kebutuhan transportasi, yang dalam suatu pergerakan selalu menimbulkan permasalahan, khususnya pada saat orang ingin bergerak untuk tujuan yang sama dalam daerah tertentu dan saat yang bersamaan. Untuk pemenuhan meningkatnya kebutuhan transportasi tersebut, diperlukan suatu moda transportasi yang dapat mengangkut baik orang maupun barang dalam jumlah besar, dalam waktu yang singkat, menghemat penggunaan ruang, memiliki tingkat pencemaran yang rendah, mempunyai faktor keamanan yang tinggi, dan lebih efisien dibandingkan dengan moda transportasi jalan untuk angkutan jarak jauh dan untuk daerah yang padat lalu lintasnya. Dari karakteristik itu, moda transportasi tersebut adalah kereta api.

Moda Raya Terpadu Jakarta (MRT Jakarta) merupakan sarana perkeretaapian dengan sistem transit cepat menggunakan kereta rel listrik di Jakarta. Di era saat ini, moda transportasi tersebut menjadi primadona di kalangan rakyat karena selain dari segi harganya yang terjangkau juga karena tingkat keamanan dan kenyamanan.

Menurut Undang-Undang Nomor 23 Tahun 2007 tentang perkeretaapian, transportasi kereta api adalah moda transportasi darat yang memiliki keunggulan dibanding dengan moda transportasi darat lainnya, yaitu dapat mengangkut penumpang atau barang dalam jumlah yang besar dengan waktu yang relatif singkat serta tingkat keselamatan dan keamanan yang tinggi. Tingkat keselamatan dan keamanan yang tinggi dapat dicapai apabila kondisi prasarana dalam keadaan baik. Prasarana merupakan segala sesuatu yang merupakan penunjang utama terselenggaranya suatu proses, oleh karena itu prasarana dalam bidang tranportasi kereta api merupakan faktor utama dalam kelancaran operasional transportasi kereta api.

Prasarana transportasi kereta api menurut Peraturan Pemerintah Nomor 56 Tahun 2009 terdiri dari jalur kereta api, stasiun kereta api, dan fasilitas operasi kereta api agar kereta api dapat dioperasikan. Jalur kereta api adalah jalur yang terdiri atas rangkaian petak jalan rel yang meliputi ruang manfaat jalur kereta api, ruang milik jalur kereta api, dan ruang pengawasan jalur kereta api, termasuk bagian atas dan bawahnya yang diperuntukan bagi lalu lintas kereta api. Jalur kereta api yang menjadi cakupan wilayah tanggung jawab Track Maintenance Section MRT Jakarta adalah Lintas Lebak Bulus - Bundaran HI.

Menurut Peraturan Menteri Perhubungan Nomor PM 32 Tahun 2011 Tentang Standar dan Tata Cara Pemeriksaan Prasarana Perkeretaapian pada Pasal 2 menyebutkan bahwa setiap penyelenggara prasarana perkeretaapian wajib melakukan pemeriksaan terhadap prasarana yang dioperasikan untuk mengetahui kondisi dan fungsi prasarana perkeretaapian, serta Menurut Peraturan Menteri Perhubungan Nomor PM 32 Tahun 2011 Tentang Standar Dan Tata Cara Perawatan Prasarana Perkeretaapian pada Pasal 2 menyebutkan bahwa setiap penyelenggara prasarana perkeretaapian wajib melakukan perawatan terhadap prasarana yang dioperasikan untuk mempertahankan kehandalan prasarana perkeretaapian agar tetap laik operasi.

Peranan dari prasarana memegang kedudukan yang sangat penting karena prasarana kereta api merupakan salah satu faktor utama dalam kelancaran pengoperasian kereta api. Dengan melihat kedudukannya yang sangat penting tersebut, maka kondisi dari prasarana tersebut harus baik. Oleh karena itu, perlu adanya perencanaan kegiatan perawatan dan pemeliharaan prasarana kereta api.

Pada PT MRT Jakarta khususnya dalam kegiatan perawatan dan pemeliharaan jalan rel pada lintas Lebak Bulus-Bundaran HI menjadi daerah tanggung jawab dari track maintenance section. 
Track Maintenance Section dipimpin oleh 3 orang Section Head dan 12 orang staf yang mempunyai tugas pokok dan tanggung jawab melaksanakan pemantauan, pengawasan, pemeriksaan, dan pembinaan mutu teknis permeliharaan jalan rel. Hal ini bertujuan untuk menjamin kelaikan Jalan Rel di wilayah kerjanya secara administrasi dan teknis serta secara rutin membuat perencanaan.

Kelelahan atau fatigue adalah penurunan kemampuan dan efisiensi mental serta fisik yang disebabkan oleh adanya aktivitas mental dan/atau fisik yang berlebihan. Kelelahan dapat dibagi menjadu dua jenis, yaitu kelelahan fisik dan kelelahan mental. Kelelahan mental didefinisikan sebagai suatu keadaan psikobiologis yang disebabkan oleh aktivitas kognitif yang berlebihan dan memberikan manifestasi berupa penurunan kemampuan kognitif. Kelelahan fisik terjadi saat melakukan pekerjaan fisik, otot yang digunakan pada aktivitas tersebut akan menjadi lelah akibat akumulasi berbagai zat metabolik.

Pada bulan maret 2020 MRT secara resmi memulai pembangunan fase 2a dimulai dari stasiun bundaran HI hingga stasiun Kota dengan total panjang jalur 6 kilometer dan terdiri dari 7 stasiun bawah tanah yaitu Stasiun Thamrin, Stasiun Monas, Stasiun Harmoni, Stasiun Sawah Besar, Stasiun Mangga Besar, Stasiun Glodok, dan Stasiun Kota.

\section{B. LITERATURE REVIEW}

\section{Aspek Legalitas}

Dari aspek legalitas menyajikan peraturan perundang-undangan yang merupakan dasar hukum dalam penyelenggaraan perkeretaapian. Dasar hukum yang berlaku saat ini antara lain: Undang - Undang Nomor 23 Tahun 2007 Tentang Perkeretaapian. Pada Pasal 1, yaitu: a) Kereta api adalah sarana perkeretaapian dengan tenaga gerak, baik berjalan sendiri maupun dirangkaikan dengan sarana perkeretaapian lainnya, yang akan ataupun sedang bergerak di jalan rel yang terkait dengan perjalanan kereta api; b) Prasarana perkerataapian adalah jalur kereta api, stasiun kereta api, dan fasilitas operasi kereta api agar kereta api dapat dioperasikan; dan c) Jalur kereta api adalah jalur yang terdiri atas rangkaian petak jalan rel yang meliputi ruang manfaat jalur kereta api, ruang milik jalur kereta api, dan ruang pengawasan jalur kereta api, termasuk bagian atas dan bawahnya yang diperuntukkan bagi lalu lintas kereta api.

Peraturan Menteri Nomor 32 Tahun 2011 Tentang Standar Dan Tata Cara Perawatan Prasarana Perkeretaapian, yaitu pada pasal: 4) Perawatan prasarana perkeretaapian sebagaimana dimaksud dalam pasal 2 harus dilakukan sesuai dengan pedoman perawatan yang disusun oleh penyelenggara prasarana perkeretaapian berdasarkan jenis prasarana perkeretaapian; dan 6) Perawatan prasarana perkeretaapian sebagaimana yang dimaksud dalam pasal 3 harus dilakukan oleh tenaga perawatan yang telah memiliki sertifikat kompetensi dengan menggunakan peralatan perawatan sesuai dengan jenis prasarana perkeretaapian.

Peraturan Menteri Nomor 9 Tahun 2017 Tentang Sertifikasi Tenaga Pemeriksa Prasarana Perkeretaapian, yaitu pada pasal: 6) Untuk mendapat sertifikat kompetensi Tenaga Pemeriksa Jalur dan Bangunan Kereta Api sebagaimana dimaksud dalam pasal 4 huruf a, harus memenuhi persyaratan: Sertifikat Keahlian Tenaga Pemeriksa Jalur dan Bangunan Kereta Api tingkat pelaksana yaitu: a) pria atau wanita; b) sehat jasmani dan rohani; c) tidak buta warna; d) lulus pendidikan sekolah lanjutan tingkat atas dan lulus pendidikan dan pelatihan dasar Tenaga Pemeriksa Jalur dan Bangunan Kereta Api, atau lulus pendidikan sekolah lanjutan tingkat atas dan telah bekerja / magang paling sedikit 2 (dua) tahun di bidang Pemeriksa Jalur dan Bangunan Kereta Api, atau lulus pendidikan di bidang perkeretaapian setingkat Diploma III; e) lulus Pendidikan dan 
Pelatihan Tenaga Pemeriksa Jalur dan Bangunan Kereta Api tingkat Pelaksana; dan lulus uji kompetensi sebagai Tenaga Pemeriksa Jalur dan Bangunan Kereta Api tingkat Pelansana.

Undang-Undang Nomor 13 Tahun 2003 Tentang Ketenagakerjaan pada Pasal 7 ayat (1), Dalam rangka pembangunan ketenagakerjaan, pemerintah menetapkan kebijakan dan menyusun perencanaan tenaga kerja; dan Pasal 8 ayat (3), ketentuan mengenai tata cara memperoleh informasi ketenagakerjaan dan penyusunan serta pelaksanaan perencanaan tenaga kerja sebagaimana dimaksud dalam ayat (1) diatur dengan Peraturan Pemerintah.

\section{Aspek Teoritis}

Menurut Komaruddin (1996) dikutip dari Zaenuri (2015) Manajemen Sumber Daya Manusia di Pemerintahan Edisi I, analisa beban kerja adalah proses untuk menetapkan jumlah jam kerja orang yang digunakan atau dibutuhkan untuk merampungkan suatu pekerjaan dalam waktu tertentu, atau dengan kata lain analisis beban kerja bertujuan untuk menentukan berapa jumlah personalia dan berapa jumlah tanggung jawab atau beban kerja yang tepat dilimpahkan kepada seorang petugas.

Menurut Zaenuri (2015) dalam Manajemen Sumber Daya Manusia di Pemerintahan Edisi I, analisis beban kerja adalah frekuensi rata-rata masing-masing jenis pekerjaan dalam jangka waktu tertentu dari masing-masing organisasi, misalnya berapa banyaknya pekerjaan pengetikan surat atau naskah lainnya yang harus dibuat oleh suatu satuan organisasi dalam jangka waktu tertentu.

Menurut Moeljadi (1992) dikutip dari Zaenuri (2015) Manajemen Sumber Daya Manusia di Pemerintahan Edisi I, mengemukakan perencanaan tenaga kerja dalam jangka panjang ditentukan oleh sisi permintaan perusahaan, yaitu perkiraan kebutuhan tenaga kerja dan sisi penawaran yaitu ketersediaan tenaga kerja di pasar. Perkiraan kebutuhan tenaga kerja perusahaan ditentukan oleh perkiraan tersedianya tenaga kerja di perusahaan dan rencana-rencana perusahaan. Sedangkan perkiraan tersedianya tenaga kerja itu sendiri, ditentukan dari analisis beban kerja, analisis perpindahan tenaga kerja dan analisis kelebihan atau kekurangan tenaga kerja. Analisis kelebihan atau kekurangan tenaga kerja perusahaan, berkaitan dengan besarnya jumlah tenaga kerja yang ada pada perusahaan tersebut berada pada kondisi berlebih atau kurang jika dikaitkan dengan beban kerja. Analisis tersebut dapat dilaksanakan jika sudah diketahui beban kerjanya. Analisis beban kerja sendiri memberikan arahan tentang produktivitas. Produktivitas kerja dapat digambarkan dalam efisiensi penggunaan tenaga kerja, dimana tenaga kerja tersebut akan dapat digunakan secara efisien jika jumlah tenaga kerja yang ada seimbang dengan beban kerjanya.

Berdasarkan uraian di atas, maka dapat disimpulkan bahwa analisis beban kerja adalah proses yang bertujuan untuk menetapkan jumlah pekerja yang dibutuhkan untuk menyelesaikan suatu tanggung jawab atau beban kerja dalam jangka waktu tertentu. Sehingga terciptanya efisiensi penggunaan tenaga kerja dikarenakan beban kerja seimbang dengan tenaga kerja yang tersedia.

\section{Kebutuhan dan Perhitungan}

Menurut Hasibuan (1990) Manajement Sumber Daya Manusia Edisi Revisi 2019, menjelesankan perencanaan sumber daya manusia adalah merencanakan tenaga kerja agar sesuai dengan kebutuhan perusahaan serta efektif dan efisien dalam membantu terwujudnya tujuan. Umumnya proses perencanaan Sumber Daya Manusia (SDM) dibagi atas dua tahapan besar, yaitu tahapan peramalan kebutuhan SDM dan perencanaan program.

Menurut James Walker (1986) dikutip dari Zaenuri (2015) Manajemen Sumber Daya Manusia di Pemerintahan Edisi I, Perkiraan kebutuhan adalah proses penentuan jumlah sumber daya manusia yang dibutuhkan organisasi dimasa yang akan datang. Perkiraan kebutuhan tersebut 
diturunkan dari sejumlah informasi seperti analisis kondisi eksternal, kemampuan SDM, dinamika organisasi saat ini, potensi SDM organisasi, rancangan perkerjaan, folosofi manajemen, anggaran, mutasi, promosi, dan lain lain. Sedangkan perencanaan program dilakukan setelah selesainya perkiraan kebutuhan.

Menurut Zaenuri (2015) Manajemen Sumber Daya Manusia di Pemerintahan Edisi I, Organisasi pada umumnya mempunyai anggaran dan rencana-rencana jangka pendek secara terinci. Budget organisasi ini memberikan otorisasi finansial untuk penambahan pegawai. Jumlah tenaga kerja yang diperlukan untuk menyelesaikan suatu pekerjaan dapat ditentukan yaitu pertama-tama dengan menentukan jumlah waktu yang sungguh-sungguh diperlukan untuk menyelesaikan pekerjaan.

Dikatakan lebih lanjut, waktu tersebut diperoleh berdasarkan studi waktu dan gerak. Kemudian langkah berikutnya dengan menentukan persentase dari waktu yang dipergunakan untuk kegiatan-kegiatan yang tidak langsung berhubungan tetapi bermanfaat bagi organisasi, waktu untuk menghilangkan kelelahan, dan waktu untuk keperluan pribadi. Masing-masing waktu tersebut kemudian dijumlahkan sehingga diperoleh jumlah waktu yang diperlukan untuk menyelesaikan jabatan. Selanjutnya, jumlah waktu yang diperlukan untuk menyelesaikan jabatan dibagi dengan jumlah waktu yang disediakan untuk menyelesaikan jabatan tersebut. Hasil pembagian dikalikan dengan satu orang, sehingga diperoleh jumlah tenaga kerja yang diperlukan Selain itu penentuan jumlah tenaga kerja yang lebih tepat dapat dilakukan dengan menambahkan jumlah tenaga kerja yang telah dihitung dengan persentase tertentu atau persentase kelonggaran. Persentase ini menunjukan besarnya kelonggaran yang dapat diterima akibat ketidakhadiran pegawai karena alasan sakit, meninggal dan alasan-alasan lainnya. Metode perhitungan yang dapat digunakan lainnya adalah melalui perhitungan kebutuhan pegawai berdasarkan beban kerja seperti yang terdapat dalam pedoman penyusunan perencanaan tenaga kerja mikro di perusahaan, badan usaha milik negara dan badan usaha milik daerah (Kep. Men. Tenaga Kerja dan Transmigrasi Nomor : 52 tahun 2014), tertanggal 11 Februari 2014.

Perhitungan kebutuhan pegawai dalam jabatan dalam modul pedoman perhitungan tersebut menggunakan acuan dasar data pegawai yang ada serta peta dan uraian jabatan, maka alat pokok yang dipergunakan dalam menghitung kebutuhan pegawai adalah uraian jabatan yang telah tersusun rapi. Jumlah kebutuhan pegawai dihitung dengan mengidentifikasi beban kerja melalui beberapa pendekatan, yaitu hasil kerja dan tugas per tugas jabatan. Berikut ini uraian lebih lanjut mengenai pendekatan-pendekatan yang dapat dilakukan untuk menghitung kebutuhan pegawai berdasarkan beban kerja, sesuai dengan pedoman Penyusunan Perencanaan Tenaga Kerja Mikro di Perusahaan Berdasarkan Beban Kerja :

Pendekatan Hasil Kerja Hasil kerja adalah produk atau output jabatan. Metode dengan pendekatan hasil kerja adalah menghitung formasi dengan mengidentifikasi beban kerja dari hasil kerja jabatan. Metoda ini dipergunakan untuk jabatan yang hasil kerjanya fisik atau bersifat kebendaan, atau hasil kerja non fisik tetapi dapat dikuantifiisir. Perlu diperhatikan, bahwa metoda ini efektif dan mudah digunakan untuk jabatan yang hasil kerjanya hanya satu jenis. Informasi yang diperlukan dalam menggunakan metode ini adalah wujud hasil kerja dan satuannya, jumlah beban kerja yang tercermin dari target hasil kerja yang harus dicapai, dan standar kemampuan ratarata untuk memperoleh hasil kerja.

Work Sampling. Menurut Sritomo (1989) dikutip dari Hudaya (2013) pengukuran kinerja teller dengan menggunakan metode sampling pekerja di bank bri unit, menyatakan sampling kerja atau sering disebut sebagai work sampling, Ratio Delay Study atau Random Observation Method adalah salah satu teknik untuk mengadakan sejumlah besar pengamatan terhadap aktivitas kerja 
dari mesin, proses atau pekerja/operator.Pengukuran kerja dengan cara ini juga diklasifikasikan sebagai pengukuran kerja secara langsung. Karena pelaksanaan kegiatan pengukuran harus dilakukan secara langsung ditempat kerja yang diteliti.

\section{METODE}

Penelitian ini menggunakan jenis penelitian kualitatif dengan pendekatan analisis deskriptif. Jenis data yang digunakan dalam penelitian ini berjenis data primer dan data sekunder yang diperoleh dari hasil pengamatan di lapangan maupun intansi terkait, selanjutnya data tersebut diproses mulai dari meng-input sampai didapatkan output melalui analisis dengan metode-metode yang dapat diterima secara ilmiah: 1) Mengidentifikasi masalah; 2) pengumpulan data; 3) pengolahan data; dan 4) keluaran.

Desain penelitian atau metode penelitian diartikan sebagai cara ilmiah untuk mendapatkan data dengan tujuan dan kegunaan tertentu. Penelitian ini dilakukan untuk merencanakan kebutuhan SDM di MRT Jakarta khususnya pada track maintenance section. Sehubungan dengan hal tersebut, maka dalam pelaksanaan penelitian ini akan menggunakan pendekatan pengamatan secara langsung (observasi lapangan) yang dilaksanakan melalui pengumpulan data di lapangan dan melakukan wawancara lalu mengisi formulir work sampling yang dilakukan oleh peneliti untuk mencatat aktifitas pekerjaan yang dilakukan.

Pengumpulan data primer berupa standar kemampuan rata-rata waktu penyelesaian dan kuantitas beban tugas-tugas pokok pekerjaan. Pengumpulan data untuk tujuan mengidentifikasi tugas- tugas pokok pekerjaan akan dilakukan dengan metode gabungan wawancara dan observasi. Data sekunder seperti teori yang dipakai, maupun informasi terkait objek penelitian dikumpulkan melalui buku, skripsi, situs-situs internet, maupun dokumen-dokumen yang dimiliki perusahaan. Tahap pengolahan data dilakukan melaui dua tahapan, yang pertama yaitu adalah melakukan pemeriksaan terhadap data yang telah diperoleh pada lembar pengamatan work sampling. Pemeriksaan ditinjau dari segi kelengkapan atau jika ada kesalahan maupun ketidak konsistenan data pengamatan. Kegiatan yang telah dikelompokkan berdasarkan kategori kegiatan maintenance masing- masing kemudian dihitung jumlahnya. Selanjutnya data yang berasal dari lembar pengamatan dipindahkan ke dalam komputer untuk diolah. Langkah kedua, memasukkan data mengenai standar kemampuan rata-rata waktu penyelesaian tugas-tugas pokok pekerjaan selama satu tahun ke dalam rumus perhitungan kebutuhan tenaga kerja berdasarkan beban kerja. Proses perhitungan akan dibantu dengan Microsoft Excel.

\section{HASIL DAN PEMBAHASAN}

Dalam melakukan kegiatan perawatan dan pemeliharaan prasarana perkeretaapian khususnya dibidang track, sumber daya manusia merupakan faktor yang mempengaruhi dalam pelaksanaan kegiatan tersebut. Tujuan utama dari perawatan dan pemeliharaan adalah untuk menjaga kualitas dan kelaikan serta umur dari prasarana untuk menjamin kelancaran pelayanan angkutan kereta api. Keberhasilan kegiatan perawatan tidak lepas dari sumber daya manusia dalam melaksanakan tugas yang memiliki waktu penyelesaian tugas yang berbeda-beda.

\section{Sumber Daya Manusia Track Maintenence Section MRT Jakarta}

Secara keseluruhan jumlah pegawai Track Maintenance Section MRT Jakarta berjumlah 15 orang pegawai. Terdiri dari 3 orang kepala seksi (section head) dan 12 orang staff. Kepala seksi memiliki tugas untuk merencanakan, pengawasan, dan memberi instruksi saat pada setiap kegiatan. Dalam penggolongannya, pegawai di Track Maintenance Section MRT Jakarta terbagi 
atas 2 tipe shift kerja yaitu normal shift dan maintenance shift. Pegawai yang bekerja pada normal shift memiliki tugas untuk mengurus segala administrasi yang berhubungan dengan kegiatan maintenance di track. Contohnya seperti melakukan penyusunan jadwal kegiatan maintenance, surat menyurat, pengurusan izin kerja, laporan hasil kegiatan maintenance, dan kegiatan lainnya yang berhubungan dengan kegiatan administrasi. Sedangkan pegawai maintenance shift bertugas menangani secara langsung kegiatan perawatan dan pemeliharaan jalan rel. Pembagian kerja pegawai Track Maintenance Section MRT Jakarta disajikan dalam tabel berikut:

Tabel 1. Pembagian kerja pegawai Track Maintenance Section MRT Jakarta

\begin{tabular}{|c|c|c|c|}
\hline No & Pegawai & Shift & Jumlah \\
\hline 1 & Normal Shift & Normal & 1 \\
\hline \multirow{2}{*}{2} & & Shift 1 & 4 \\
\hline 3 & \multirow{2}{*}{ Maintenance Shift } & Shift 2 & 5 \\
\cline { 4 - 4 } \cline { 3 - 4 } & & Shift 3 & 5 \\
\hline \multicolumn{2}{|c|}{ Total } & 15 \\
\hline
\end{tabular}

Sumber: data diolah

Umur pegawaiTrack Maintenance Section MRT Jakarta didominasi oleh pegawai berumur 21-30 tahun sebesar 80\% dan 31- 40 tahun sebesar 20\%. Dari data tersebut kinerjanya mengalami perbedaan bagi setiap pegawai. Pegawai dengan umur 21-30 tahun memiliki kinerja yang baik dalam hal tenaga saat melakukan pemeliharaan dan perawatan. Sedangkan pegawai dengan umur 31-40 tahun mudah lelah dalam hal tenaga, tetapi memiliki lebih banyak ilmu dan pengalaman saat di lapangan dibanding pegawai yang lebih muda.

Selanjutnya, Track Maintenance Section MRT Jakarta menerapkan sistem shift dalam pelaksanaan pekerjaan di MRT Jakarta, dapat dilihat pada tabel berikut ini:

Tabel 2. Jam Kerja Pegawai

\begin{tabular}{|c|c|c|c|c|}
\hline No & Hari Kerja & Waktu Kerja & Waktu Istirahat & Jumlah (Jam) \\
\hline 1 & \multirow{4}{*}{ Senin - Jumat } & $08.00-17.00$ & $12.00-13.00$ & 8 \\
\hline 2 & & $06.00-15.00$ & $12.00-13.00$ & 8 \\
\hline 3 & & $14.00-23.00$ & $18.00-19.00$ & 8 \\
\hline 4 & & $22.00-07.00$ & $04.00-05.00$ & 8 \\
\hline 5 & \multirow{3}{*}{ Sabtu -Minggu } & $06.00-15.00$ & $12.00-13.00$ & 8 \\
\hline 6 & & $14.00-23.00$ & $18.00-19.00$ & 8 \\
\hline 7 & & $22.00-07.00$ & $04.00-05.00$ & 8 \\
\hline \multicolumn{4}{|c|}{ Rata - Rata } & 8 \\
\hline
\end{tabular}

Sumber: data diolah

Tabel 3. Pendidikan pegawai TMC MRT Jakarta

\begin{tabular}{|c|c|}
\hline Pendidikan & Jumlah \\
\hline SMK & 1 \\
\hline
\end{tabular}




\begin{tabular}{|c|c|}
\hline D3 & 1 \\
\hline S1 & 11 \\
\hline S2 & 2 \\
\hline Jumlah & 15 \\
\hline
\end{tabular}

Sumber: data diolah

Berdasarkan tabel di atas dapat disimpulkan bahwa rata-rata jam pegawai Track Maintenance Section MRT Jakarta dalam satu hari adalah 8 jam. Berdasarkan standar Internation Labour Organization (ILO) jam kerja Track Maintenance Section MRT Jakarta sudah sesuai. Berdasarkan karakteristik pegawai Track Maintenance Section tersebut, kinerja dari masingmasing pegawai mengalami perbedaan yang cukup signifikan, dimana pegawai yang dengan pendidikan Magister lebih banyak melakukan kegiatan manajemen dan perencanaan, sedangkan pegawai dengan pendidikan S1 dan D3 lebih produktif dapat mengambil keputusan saat dilapangan dibanding dengan pendidikan SMK yang lebih produktif dalam kegiatan berat saja.

\section{Pembangunan Fase 2a MRT Jakarta}

Pada fase 2a dimulai dari Stasiun Bundaran HI hingga Stasiun Kota dengan total panjang jalur 6 kilometer dan terdiri dari 7 stasiun bawah tanah yaitu Stasiun Thamrin, Stasiun Monas, Stasiun Harmoni, Stasiun Sawah Besar, Stasiun Mangga Besar, Stasiun Glodok, dan Stasiun Kota.

Penambahan jalur pada fase 2a ini berdampak terhadap kegiatan maintenance yang ada di MRT Jakarta khususnya pada track maintenance section, salah satu dampaknya yaitu penambahan beban kerja yang diterima. Hal ini disebabkan bertambahnya jalur yang harus dirawat dan metode perawatan yang digunakan diasumsikan sama dengan fase 1, tentunya tidak semua kegiatan yang terdampak akibat adanya penambahan jalur tersebut, berikut kegiatan maintenance yang terdampak setelah pembangunan fase 2a stasiun Bundaran HI-Kota:

Tabel 4. Aktifitas yang mengalami pertambahan beban kerja

\begin{tabular}{|c|c|c|c|c|c|}
\hline No & \multicolumn{2}{|c|}{ Rincian \& Uraian Tugas } & Norma Waktu & Target Beban & $\begin{array}{c}\text { Volume Kerja (Jam } \\
\text { per }\end{array}$ \\
\hline \multirow{8}{*}{1} & \multirow{8}{*}{$\begin{array}{l}\text { Track Patrol } \\
\text { On Foot }\end{array}$} & Pembuatan JSA & 1 & $12 * 1$ & 12 \\
\hline & & $\begin{array}{c}\text { Persiapan Form, JSA, PTW } \\
\text { dan Tools Pemeriksaan }\end{array}$ & 2 & $12 * 12$ & 288 \\
\hline & & Toolbox Meeting & 0,5 & $12 * 12$ & 72 \\
\hline & & $\begin{array}{c}\text { Pelaksanaan Pekerjaan di } \\
\text { Lapangan }\end{array}$ & 5 & $12 * 12$ & 720 \\
\hline & & $\begin{array}{c}\text { Pembuatan Laporan Hasil } \\
\text { Pekerjaan }\end{array}$ & 2,5 & $12 * 12$ & 360 \\
\hline & & $\begin{array}{c}\text { Pembuatan Summary } \\
\text { Hasil Laporan } \\
\text { Pemeriksaan }\end{array}$ & 9 & $12 * 3$ & 324 \\
\hline & & $\begin{array}{c}\text { Analisa Hasil Track Patrol } \\
\text { on Foot }\end{array}$ & 9 & $12 * 1$ & 108 \\
\hline & & Pengarsipan Dokumen & 9 & $12 * 1$ & 108 \\
\hline
\end{tabular}


Vol. 11 No. 1 (2020): Jurnal Penelitian Sekolah Tinggi Transportasi Darat

\begin{tabular}{|c|c|c|c|c|c|}
\hline \multirow{8}{*}{2} & \multirow{8}{*}{$\begin{array}{l}\text { Pemeriksaan } \\
\text { Rail Joint } \\
\text { Gap }\end{array}$} & Pembuatan JSA & 1 & $2 * 1$ & 2 \\
\hline & & $\begin{array}{c}\text { Persiapan Form, JSA, PTW } \\
\text { dan Tools Pemeriksaan }\end{array}$ & 2 & $2 * 18$ & 72 \\
\hline & & Toolbox Meeting & 0,5 & $2 * 18$ & 18 \\
\hline & & $\begin{array}{c}\text { Pelaksanaan Pekerjaan di } \\
\text { Lapangan }\end{array}$ & 5 & $2 * 18$ & 180 \\
\hline & & $\begin{array}{l}\text { Pembuatan Laporan Hasil } \\
\text { Pekerjaan }\end{array}$ & 2,5 & $2 * 18$ & 90 \\
\hline & & $\begin{array}{c}\text { Pembuatan Summary } \\
\text { Hasil Laporan } \\
\text { Pemeriksaan }\end{array}$ & 9 & $2 * 3$ & 54 \\
\hline & & $\begin{array}{c}\text { Analisa Hasil Pemeriksaan } \\
\text { Rail Joint Gap } \\
\end{array}$ & 9 & $2 * 1$ & 18 \\
\hline & & Pengarsipan Dokumen & 9 & $2 * 1$ & 18 \\
\hline \multirow{8}{*}{3} & \multirow{8}{*}{$\begin{array}{c}\text { Pemeriksaan } \\
\text { Wesel dan } \\
\text { Scissor } \\
\text { Crossing }\end{array}$} & Pembuatan JSA & 1 & $4 * 1$ & 4 \\
\hline & & $\begin{array}{c}\text { Persiapan Form, JSA, PTW } \\
\text { dan Tools Pemeriksaan }\end{array}$ & 2 & $4 * 14$ & 112 \\
\hline & & Toolbox Meeting & 0,5 & $4 * 14$ & 28 \\
\hline & & $\begin{array}{l}\text { Pelaksanaan Pekerjaan di } \\
\text { Lapangan }\end{array}$ & 5 & $4 * 14$ & 280 \\
\hline & & $\begin{array}{c}\text { Pembuatan Laporan Hasil } \\
\text { Pekerjaan }\end{array}$ & 2,5 & $4 * 14$ & 140 \\
\hline & & $\begin{array}{c}\text { Pembuatan Summary } \\
\text { Hasil Laporan } \\
\text { Pemeriksaan }\end{array}$ & 9 & $4 * 3$ & 108 \\
\hline & & $\begin{array}{c}\text { Analisa Hasil Pemeriksaan } \\
\text { Wessel dan SC }\end{array}$ & 9 & $4 * 1$ & 36 \\
\hline & & Pengarsipan Dokumen & 9 & $4 * 1$ & 36 \\
\hline
\end{tabular}

Sumber: data diolah

Tabel 5. Aktivitas yang mengalami pertambahan beban kerja

\begin{tabular}{|c|c|c|c|c|c|}
\hline No & \multicolumn{2}{|r|}{ Rincian \& Uraian Tugas } & $\begin{array}{l}\text { Norma } \\
\text { Waktu } \\
\text { (Jam) }\end{array}$ & $\begin{array}{c}\text { Target } \\
\text { Beban } \\
\text { Kerja } \\
\text { (Unit) }\end{array}$ & $\begin{array}{c}\text { Volume } \\
\text { Kerja } \\
\text { (Jam per } \\
\text { tahun) }\end{array}$ \\
\hline \multirow{7}{*}{4} & \multirow{7}{*}{$\begin{array}{l}\text { Pemeriksaan } \\
\text { Track } \\
\text { Irregularity } \\
\text { dengan Track } \\
\text { Master }\end{array}$} & Pembuatan JSA & 1 & $4 * 1$ & 4 \\
\hline & & $\begin{array}{l}\text { Persiapan Form, JSA, } \\
\text { PTW dan Tools } \\
\text { Pemeriksaan }\end{array}$ & 2 & $4 * 12$ & 96 \\
\hline & & Toolbox Meeting & 0,5 & $4 * 12$ & 24 \\
\hline & & $\begin{array}{l}\text { Pelaksanaan Pekerjaan di } \\
\text { Lapangan }\end{array}$ & 5 & $4 * 12$ & 240 \\
\hline & & $\begin{array}{l}\text { Pembuatan Laporan Hasil } \\
\text { Pekerjaan }\end{array}$ & 2,5 & $4 * 12$ & 120 \\
\hline & & $\begin{array}{l}\text { Pembuatan Summary } \\
\text { Hasil Laporan } \\
\text { Pemeriksaan }\end{array}$ & 9 & $4 * 3$ & 108 \\
\hline & & $\begin{array}{l}\text { Analisa Hasil Pemeriksaan } \\
\text { Track Irregularity }\end{array}$ & 9 & $4 * 4$ & 144 \\
\hline
\end{tabular}




\begin{tabular}{|c|c|c|c|c|c|}
\hline & & Pengarsipan Dokumen & 9 & $4 * 1$ & 36 \\
\hline \multirow{8}{*}{5} & \multirow{8}{*}{$\begin{array}{l}\text { Pemeriksaan } \\
\text { Expansion } \\
\text { Rail Joint }\end{array}$} & Pembuatan JSA & 1 & $4 * 1$ & 4 \\
\hline & & $\begin{array}{l}\text { Persiapan Form, JSA, } \\
\text { PTW dan Tools } \\
\text { Pemeriksaan } \\
\end{array}$ & 2 & $1 * 4 * 8$ & 64 \\
\hline & & Toolbox Meeting & 0,5 & $4 * 8$ & 16 \\
\hline & & $\begin{array}{l}\text { Pelaksanaan Pekerjaan di } \\
\text { Lapangan }\end{array}$ & 5 & $4 * 8$ & 160 \\
\hline & & $\begin{array}{l}\text { Pembuatan Laporan Hasil } \\
\text { Pekerjaan }\end{array}$ & 2,5 & $4 * 8$ & 80 \\
\hline & & $\begin{array}{l}\text { Pembuatan Summary } \\
\text { Hasil Laporan } \\
\text { Pemeriksaan }\end{array}$ & 9 & $4 * 3$ & 108 \\
\hline & & $\begin{array}{l}\text { Analisa Hasil Pemeriksaan } \\
\text { EJ }\end{array}$ & 9 & $4 * 1$ & 36 \\
\hline & & Pengarsipan Dokumen & 9 & $4 * 1$ & 36 \\
\hline \multirow{7}{*}{6} & \multirow{7}{*}{$\begin{array}{l}\text { Pemeriksaan } \\
\text { Cabin Ride }\end{array}$} & $\begin{array}{l}\text { Persiapan Form } \\
\text { Pemeriksaan }\end{array}$ & 0,25 & $12 * 20$ & 60 \\
\hline & & Toolbox Meeting & 0,25 & $12 * 20$ & 60 \\
\hline & & $\begin{array}{l}\text { Pelaksanaan Pekerjaan di } \\
\text { Lapangan }\end{array}$ & 4 & $12 * 20$ & 960 \\
\hline & & $\begin{array}{l}\text { Pembuatan Laporan Hasil } \\
\text { Pekerjaan }\end{array}$ & 0,5 & $12 * 20$ & 120 \\
\hline & & $\begin{array}{l}\text { Pembuatan Summary } \\
\text { Hasil Laporan } \\
\text { Pemeriksaan } \\
\end{array}$ & 9 & $12 * 5$ & 540 \\
\hline & & Analisa Hasil Cabin Ride & 9 & $12 * 1$ & 108 \\
\hline & & Pengarsipan Dokumen & 9 & $12 * 1$ & 108 \\
\hline
\end{tabular}

Sumber: data diolah

Berdasarkan dari tabel Pertambahan aktivitas beban kerja di atas dapat disimpulkan penambahan aktivitas beban kerja dibagi menjadi 2 kategori yaitu: 1) Norma Waktu. Norma waktu yang berubah disebabkan bertambahnya pekerjaan yang dilakukan tetapi masih dapat diselesaikan dalam satu hari kerja; 2) Beban Kerja (unit). Beban Kerja (unit), yaitu banyaknya aktivitas pekerjaan yang harus dilakukan dalam satu tahun. Beban kerja (unit) $=(12 \div$ periode pekerjaan $\mathrm{x}$ banyaknya tugas maintenance dalam satu periode).

Berikut adalah cara perhitungan beban kerja pegawai Track Maintenance Section MRT Jakarta pada tabel di atas dalam satu tahun menggunakan rumus :

a. Menghitung jumlah volume kerja dalam satu tahun $\left(\sum \mathrm{VK}\right)$, berdasarkan hasil perhitungan didapatkan volume kerja sebesar 23.605 jam atau sama dengan 2.950,63 hari dengan 8 jam kerja per hari.

b. Menghitung persentasi masuk kerja dalam satu tahun (\%MK), membagi waktu kerja efektif dengan waktu kerja yang tersedia. Waktu kerja efektif $=\{$ (hari kerja per tahun - (cuti tahunan + pendidikan \& pelatihan + hari libur nasional + ketidak hadiran)) x waktu kerja per hari. Waktu kerja yang tersedia $=$ hari kerja per tahun $\mathrm{x}$ waktu kerja per hari.

Waktu Kerja efektif $=(261$ hari kerja per tahun $-(12$ hari cuti tahunan + belum ada rencana pendidikan $\&$ pelatihan +24 hari libur nasional +0 ketidak hardiran $))$ x 8 jam kerja per hari $=$ 1800 jam kerja. 

tersedia.

Waktu kerja tersedia $=261$ hari kerja per tahun $\mathrm{x} 8$ jam kerja per hari $=2096$ jam kerja

$$
\text { Drmantam mannl, } \quad \frac{1}{8}-
$$

Pada fase 2a pegawai Track Maintenance Section MRT Jakarta memiliki jam kerja per hari selama 8 jam. Dalam seminggu terdapat 5 hari kerja, tetapi mengalami pertambahan wilayah yang menjadi tanggung jawab perawatan dan pemeliharaan sepanjang 6 kilometer. Hal ini menyebabkan bertambahnya beban pekerjaan yang dilakukan oleh staff Track Maintenance Section MRT Jakarta. Berdasarkan data yang diperoleh dari Track Maintenance Section MRT Jakarta dan perhitungan sesuai dengan Kep. Men. Tenaga Kerja dan Transmigrasi Nomor : 52 tahun 2014 tentang pedoman penyusunan perencanaan tenaga kerja mikro di perusahaan, badan usaha milik negara dan badan usaha milik daerah sebagai berikut:

Waktu Kerja Track Maintenance Section MRT Jakarta. Waktu kerja dihitung dengan menentukan jumlah hari dalam setahun, jumlah hari libur mingguan dalam setahun, jumlah hari libur nasional dalam setahun, dan jumlah cuti dalam setahun. Selanjutnya jumlah hari libur mingguan ditambahkan dengan jumlah hari libur nasional serta jumlah cuti yang menghasilkan total hari tidak bekerja atau libur, lalu jumlah hari dalam setahun itu dikurangi dengan total jumlah hari tidak bekerja. Berikut perhitungan waktu kerja efektif Track Maintenance Section MRT Jakarta.

Selanjutnya, Beban Kerja yang dihitung dalam satu tahun sesuai Kep. Men. Tenaga Kerja dan Transmigrasi Nomor : 52 tahun 2014 tentang pedoman penyusunan perencanaan tenaga kerja mikro di perusahaan, Badan Usaha Milik Negara dan Badan Usaha Milik Daerah.

Tabel 6. Kebutuhan tenaga kerja TMC MRT Jakarta fase 2a

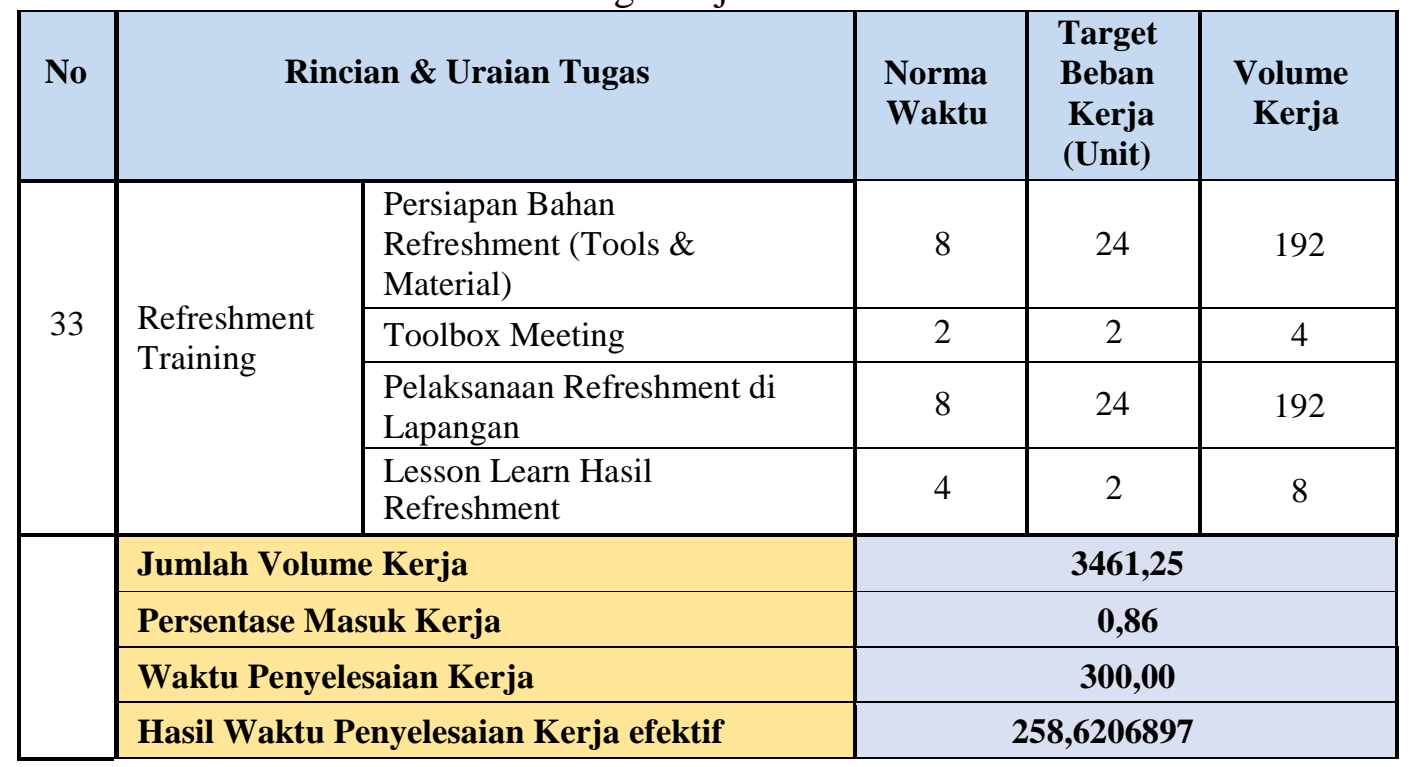




\begin{tabular}{|l|l|c|}
\hline & Perkiraan Kebutuhan Tenaga Kerja & 13,3835 \\
\cline { 2 - 3 } & Pembulatan Kebutuhan Tenaga Kerja & 14 \\
\hline
\end{tabular}

Sumber: data diolah

Berikut adalah cara perhitungan beban kerja pegawai Track Maintenance Section MRT Jakarta pada tabel di atas dalam satu tahun menggunakan rumus :

Menghitung jumlah volume kerja dalam satu tahun ( $\square \mathrm{VK})$, berdasarkan hasil perhitungan didapatkan volume kerja sebesar 27.690 jam atau sama dengan 3461,25 hari dengan 8 jam kerja per hari. Menghitung persentasi masuk kerja dalam satu tahun (\%MK), membagi waktu kerja efektif dengan waktu kerja yang tersedia. Waktu kerja efektif $=\square$ (hari kerja per tahun - (cuti tahunan + pendidikan \& pelatihan + hari libur nasional + ketidak hadiran)) x waktu kerja per hari. Waktu kerja yang tersedia $=$ hari kerja per tahun $\mathrm{x}$ waktu kerja per hari.

Waktu Kerja efektif $=(261$ hari $-(12$ hari cuti tahunan +belum ada rencana pendidikan \& pelatihan +24 hari libur nasional +0 ketidak hardiran)) x 8 jam kerja per hari $=1800$ jam kerja. Waktu kerja tersedia $=261$ hari kerja per tahun $\times 8$ jam kerja perhari $=2096$ jam kerja tersedia

Berdasarkan perhitungan di atas didapatkan hasil perkiraan kebutuhan tenaga kerja sebesar 13,13 yang dibulatkan menjadi 14 orang. Berdasarkan hasil analisis di atas untuk MRT Jakarta khususnya pada Track Maintenance Section membutuhkan penambahan tenaga kerja sebanyak 2 orang untuk melakukan pekerjaan maintenance untuk Lintas Lebak Bulus - Kota.

\section{E. KESIMPULAN}

Berdasarkan hasil penelitian ini dapat disimpulkan hasil dari perhitungan beban kerja pada Track Maintenance Section MRT Jakarta sebagai berikut: 1) Lintas Lebak Bulus - Bundaran HI. Waktu kerja Track Maintenance Section MRT Jakarta dalam satu tahun yaitu 365 hari dikurangi dengan jumlah hari libur kerja yaitu 140 hari sehingga didapatlah jumlah hari kerja efektif yaitu sebanyak 225 hari dan Hal yang dapat disimpulkan terkait dengan jumlah kebutuhan pegawai yaitu kebutuhan pegawai yang dianjurkan telah seimbang sebanyak 12 orang staff; Belum adanya rencana pendidikan dan pelatihan; 2) Setelah pembangunan fase 2a. Wilayah tanggung jawab Track Maintenance Section MRT Jakarta bertambah mulai dari Stasiun Bundaran HI - Stasiun Kota; dan Hal yang dapat disimpulkan terkait dengan jumlah kebutuhan pegawai dianjurkan sebanyak 14 orang, namun pada kenyataannya saat ini jumlah pegawai yang ada adalah 12 orang staff. Sehingga dapat dikatakan bahwa setelah pembangunan fase 2a dibutuhkan 2 orang pegawai dengan pendidikan di bidang perkeretaapian setingkat Diploma III atau lulus pendidikan sekolah lanjutan tingkat atas dan lulus pendidikan dan pelatihan dasar Tenaga Pemeriksa Jalur Kereta Api.

\section{DAFTAR PUSTAKA}

Kementerian Ketenagakerjaan, (2003). “Undang-Undang Republik Indonesia No. 13 Tahun 2003 Tentang Ketenagakerjaan”. Jakarta: Kementerian Ketenagakerjaan Republik Indonesia.

Kementerian Perhubungan, (2007). "Undang-Undang Republik Indonesia No. 23 Tahun 2007 Tentang Perkeretaapian”. Jakarta: Kementerian Perhubungan Republik Indonesia.

Kementerian Perhubungan, (2011). "Peraturan Pemerintah No. 32 Tahun 2011 Tentang Standar dan Tata Cara perawatan Prasarana Perkeretaapian”. Jakarta: Kementerian Perhubungan Republik Indonesia.

Kementerian Perhubungan, (2017). "Peraturan Menteri No. 9 Tahun 2017 Tentang Sertifikasi Tenaga Pemeriksa Prasarana Perkeretaapian". Jakarta: Kementerian Perhubungan Republik Indonesia. 
Kementerian Ketenagakerjaan, (2014). “Keputusan Menteri No. 52 Tahun 2014 Tentang Pedoman Penyusunan Perencanaan Tenaga Kerja Mikro Di Perusahaan, Badan Usaha Milik Negara Dan Badan Usaha Milik Daerah”. Jakarta: Kementerian Ketenagakerjaan Republik Indonesia.

Hasibuan, Malayu. Manajemen Sumber Daya Manusia Edisi Revisi 2019. Jakarta: PT Bumi Aksara, 2019.

Wibowo. Manajemen Sumber Daya Manusia. Surabaya: CV. R.A.De.Rozarie, 2017. Yanto. Engineering Psychology: Prinsip Dasar Rekayasa Kerja Berbasis Integrasi Fisik, Psikis, Dan Teknik. Jakarta: Penerbit Universitas Katolik Indonesia Atma jaya, 2019.

Zaenuri. Manajemen Sumber Daya Manusia di Pemerintahan Edisi I. Yogyakarta: Lembaga Penelitian, Publikasi \& Pengabdian Masyarakat (LP3M), 2015.

Hudaya, A. Pengukuran Kinerja Teller Dengan Metode Sampling Kerja Di Bank BRI Unit. Garut: Jurnal STT-Garut, 2013.

Tim PKL MRT Jakarta Lintas Lebak Bulus - Bundaran HI, Laporan umum Tim PKL MRT Jakarta Lintas Lebak Bulus - Bundaran HI. Bekasi: Sekolah Tinggi Transportasi Darat, 2020. 